\title{
Da prinsessen og halve kongeriket glapp - om skole og samfunnsintegrasjon på norsk
}

\author{
Trude Evenshaug* \\ Høgskolen i Sørøst-Norge, Drammen, Norge
}

\section{Sammendrag}

I 2014 bestemte det norske kronprinsparet seg for å ta barna ut av den offentlige skolen. Tronarvingen, prinsesse Ingrid Alexandra, begynte på Oslo International School, en privatskole med høy egenbetaling der undervisningen foregår på engelsk. Kronprinsparets begrunnelse for skolebyttet var at tronarvingen trengte «et grunnleggende nivå for å tenke, snakke og skrive på engelsk». Artikkelen tar utgangspunkt $i$ en gruppe lærerstudenters fortolkning av kronprinsparets skolevalg og foretar en pedagogisk historisk lesning av valget. Artikkelen giør bruk av innsikter fra nyere transnasjonale studier i pedagogisk historie og foreslår at fortolkningen av kronprinsparets skolevalg representerer et kritisk punkt $\mathrm{i}$ den norske kulturelle selvforståelsen. Lesningen av kronprinsparets skolevalg identifiserer kronprinsparet som den globaliserte norske elitens skolepolitiske avantgarde. Artikkelen konkluderer med at kongefamilien igjen kan synes å gripe den norske tidsånden. Denne gangen i en bevegelse mot et samfunn der det er forskjell på folk.

Nøkkelord: Pedagogisk historie; transnasjonal historiografi; kronprinsparets skolevalg; fellesskolen

\begin{abstract}
In 2014, the Norwegian crown prince couple decided to take their children out of the Norwegian public school. The heir princess Ingrid Alexandra attended Oslo International School, a private school with high tuition fees and all education given in English. The justification and reason given from the royal house was that «the princess needs a basic level of thinking, speaking and writing English». The article's point of departure is the interpretation of the royal school choice in a teacher education class. The article engages newer transnational studies in curriculum history and suggests that the interpretation of the royal school choice represents a critical point in the Norwegian cultural self-understanding. The reading of the royal family's school choice identifies the crown prince couple as the globalised Norwegian elite's avantgarde in school politics. The article suggests that the royal family again seems to catch the Norwegian Zeitgeist. This time in a move towards a less egalitarian society.
\end{abstract}

Keywords: Curriculum history; transnational historiography; the royal family's school choice; public school

Received: May 2016; Accepted: January 2017; Published: April 2017

^Korrespondanse: Trude Evenshaug, Høgskolen i Sørøst-Norge, Postboks 7053, 3007 Drammen. E-mail: tev@usn.no 


\section{Trude Evenshaug}

\section{Innledning}

I 2014 bestemte det norske kronprinsparet seg for å ta barna ut av den offentlige norske skolen. Den ti år gamle tronarvingen, prinsesse Ingrid Alexandra, forlot Jansløkka skole i Asker og begynte på Oslo International School. ${ }^{1}$ Dette var et brudd med kongefamiliens praksis gjennom tre generasjoner, der tronarvingen har gått $\mathrm{i}$ den offentlige skolen i barneskolealder.

Avisa Dagbladets førstesideoppslag om kronprinsfamiliens skolevalg i juni 2014, hadde tittelen: «Fjerner seg fra folket» (Dagbladet, 2014). Da pedagogikklæreren viser oppslaget til en gruppe tredjeårs-studenter i lærerutdanningen et drøyt år etter avisoppslagene, ${ }^{2}$ vekker det få assosiasjoner. Hun spør: Hva handler dette om? Hva står på spill? Hvem er folket? Responsen er laber. Etter litt oppfrisking av selve saken, sendes spørsmålene snarere tilbake til pedagogikklæreren: Hva er problemet? Kronprinsfamilien må da selv få velge hva slags skole barna skal gå på ....!?

Den offentlige samtalen om oppfostringen av kommende generasjoner er kilder til innsikt i en kulturs selvforståelse, både historisk og i dag, og lærerstudenter inviteres til å delta i samtalen. Kronprinsparets skolevalg for tronarvingen og det resonansrommet som valget umiddelbart fortolkes innenfor hos en gruppe viderekommende lærerstudenter, danner utgangspunkt for denne tekstens historiserende refleksjon over mulige endringer i den kulturelle selvforståelsen i Norge. Spørsmålene vil bli tematisert i lys av problemstillinger som reises i et internasjonalt forskerfellesskap, som har som uttalt ambisjon å yte motstand mot rådende globale forskningsagendaer på utdanningsfeltet (se særlig Popkewitz, 2013c, 2015; Tröhler \& Barbu, 2011). Diskusjonen knytter an til den løpende diskusjonen om den pedagogiske historieskrivningens oppdrag, problemstillinger, kilder, metoder og innsikter (se f.eks. Depaepe, 2001; Depaepe \& Simon, 2011; Doney, 2015; Evenshaug, 2001; Herbst, 1999; Hofstetter, Fontaine, Huitric, \& Picard, 2014; Popkewitz, 2013c, 2015; Tröhler, 2013, 2016; Tröhler \& Barbu, 2011). Som et bidrag fra en norsk kontekst til denne faglige samtalen, vil jeg foreta en pedagogisk historisk lesning av det norske kronprinsparets skolevalg. Kongefamilien er nasjonens fremste symbolbærere og har tradisjonelt grepet tidsånden godt. Spørsmålet er om de gjør det igjen. Mitt forslag er at fortolkningen av skolevalget representerer et kritisk punkt i vår kulturelle selvforståelse. Til avslutning løfter teksten fram en annen prinsesse enn den kongelige, i et forsøk på å skrive fram et pedagogisk håp som alternativ til skolen som omdreiningspunkt for kulturell engstelse.

\footnotetext{
${ }^{1}$ Prinsessen begynte i 5 . klasse på Oslo International School. Broren, prins Sverre Magnus, sluttet også på Jansløkka og begynte i 4 . klasse på Oslo Montessoriskole.

${ }^{2}$ Situasjonen er reell, men må forstås eksemplarisk. Den sier lite eller ingenting om denne konkrete studentgruppas kunnskaper, synspunkter og holdninger og enda mindre om norske grunnskolelærerstudenter generelt. Diskusjonen som fulgte var både reflektert og engasjert. Takk til studentene jeg fikk følge studieåret 2015-16!
} 


\section{Skolehistorie eller en ny historisering av pedagogikken?}

I en tid da globaliserte (og globaliserende) agendaer har stadig større innflytelse på nasjonal politikkutforming på utdanningsfeltet (jf. Plum, 2014), er det avgjørende å bevare et bredt perspektiv på den pedagogiske historien som forskningsinteresse. Slik jeg ser det, snevrer betegnelsen utdanningshistorie lett inn forskningsinteressen til institusjonalisert utdanning. En smal forstått utdanningshistorie går ikke bredt nok ut i det kulturelle, ideologiske og politiske i søket etter å forstå samfunnets pedagogisk relevante engstelser, håp og ambisjoner. Feltbetegnelsen pedagogisk historie tar opp i seg pedagogikkens kritiske interesse (jf. Biesta, 2011; Biesta, 2013). Betegnelsen har dermed et overskudd av mening, som åpner for andre og flere typer studier enn den institusjonaliserte utdanningens historie. Internasjonalt søkes denne utvidete interessen ivaretatt i begrepet Curriculum History, der feltbetegnelsen History of Education forstås som den snevrere interessen for institusjonalisert utdanning (Popkewitz, 2013b; Tröhler, 2013, 2016).

Amerikaneren Thomas Popkewitz har tatt til orde for at pedagogisk historie (the history of education/curriculum history) bør interessere seg for nåtidas historiske oppkomst (history of the present, se Popkewitz, 2011) på nye måter. Ambisjonen er:

to unthink the principles of historicism, to question the standards or models that order what is said, thought about and acted on as the type of subject matter in historical studies, and to provide alternative ways of thinking about the possibilities of the history of education and issues of change (Popkewitz, 2013c, Preface s. xv).

En ambisjon Popkewitz og andre forskere i det nevnte fellesskapet deler, er å utfordre den tradisjonelle skolehistorieskrivningen som framstår påfallende lik i mange land: En historie om skolens stødige utvikling mot stadig mer opplysning, mer humanisme, mer demokrati og en mer framskreden moral. I norsk sammenheng kjenner vi igjen historiene om skolen som blir stadig mer norsk og (dermed, kan det synes som) stadig mer fornuftig. ${ }^{3}$ Disse, som oftest svært selvtilfredse utviklingshistoriene, er nasjonalstatenes skolehistorier. Forslaget er ikke å vende blikket bort fra det lokale (eller nasjonale, for den del), der skolen faktisk finner sted. Ambisjonen er snarere å forstå både den lokale skolen og verden bedre ved å forfølge en transnasjonal pedagogikk-historisk forskningsinteresse frisatt fra både nasjonale og globale forskningsagendaer. Formålet er å kunne lese, fortolke og kritisk analysere folkeopplysning, skole og utdanning historisk på måter som tar høyde for kulturelle særegenheter, men som ikke skriver de nasjonale historiene restløst inn i store fortellinger (grand narratives) om globale utviklingstrender (Tröhler, 2016) mot stadig høyere (evidens-basert) opplysning.

Sveitseren Daniel Tröhler har vært opptatt av de tidvis store kulturelle særegenhetene i ulike nasjoners skolesystemer (Tröhler, 2011, 2016). Han påviser at det med få unntak er en umiddelbar sammenheng i tid mellom utviklingen av nasjonalstatenes styresett og påfølgende skolereformer. Nye konstitusjoner følges av ny skolelovgivning, som har til hensikt å skape lojale borgere av den nye staten (Tröhler, 2016). Folkestyre

\footnotetext{
${ }^{3}$ Se for eksempel Tønnessen (2011) og Roos (2014).
} 


\section{Trude Evenshaug}

forutsetter at kontrollen med massene, samfunnsintegrasjonen og disiplinen, flyttes fra ytre makt til indre tilslutning og lojalitet. Sammenhengen er kanskje ikke så oppsiktsvekkende, men et vesentlig poeng hos Tröhler er å peke på at en «lojal borger» ikke er det samme i ulike land: en fransk citoyen, en tysk Burger, en amerikansk citizen og, kunne vi legge til, en god nordmann er ikke det samme. Forestillingen om den lojale borgeren var ikke den samme da disse statsdannelsene og de tilhørende skolesystemene var nye, og det er den heller ikke i dag. Heller ikke de «demokratiene» elever i disse landene skulle og skal utdannes inn i, er like. Dette kan føre til feilslutninger i forskning på tvers av land, og det kan gi utilsiktede følger dersom rasjonalet fra dominerende kulturelle diskurser implementeres i andre land uten kontekstuell kunnskap og klokskap.

Motoren i globaliseringen av politikkutformingen på utdanningsfeltet er de internasjonale testene, som OECD-Pisa og liknende. Hele ideen med internasjonale tester, vurderings- og kvalitetssystemer, er at det skal være mulig å sammenlikne skoleresultater og utdanningssystemer på tvers av land. Det vil si at en må utvikle måleinstrumenter som ser bort fra kontekst, historisitet, kulturelle forskjeller, ulikheter i tenkemåter og verdivurderinger. Det store spørsmålet er da om en måler det samme. Det enda større spørsmålet er hva denne målevirksomheten skaper.

En globalisering av en kulturelt betinget forståelse av hva skole og utdanning skal være, og løse og bidra til å skape, fører til en globalisering av helt bestemte forståelser av hva for slags mennesker som anses som vellykkede resultater av utdanningsbestrebelsene. Slike universalitetspretensjoner er ikke noe nytt fenomen. Popkewitz har i en rekke arbeider vist hvordan religiøs retorikk, metaforikk og tematikk videreføres gjennom opplysningstida og inn i forestillingen om skolen og kunnskapssamfunnet (se f.eks. Popkewitz, 2011). Dersom en ikke evner å se at den sekulære himmelen som tegnes over utdanningsfeltet (også) er en trosforestilling, blir denne lett nådeløs.

Popkewitz' studier utfolder seg innenfor et dekonstruerende historieteoretisk paradigme (jf. Evenshaug, 2001) i et felt som tidligere gikk under betegnelsen new cultural history (Hunt, 1989). Hans dekonstruksjon av utdanningsfeltets forestillinger om mulighetene for å planlegge for forandring (change), er særlig urovekkende fordi den utfordrer pedagogikkens selvforståelse gjennom en kritikk av fagspråket og kategoriseringene det utfoldes gjennom (Popkewitz, 2013a). ${ }^{4}$ Popkewitz har selv gått empirisk til verks for å avdekke hvor lite egnet den erfaringsbaserte og praksisnære utdanningsforskningen er til å skape det den hevder å ha som mål. Uttalte utdanningspolitiske og pedagogiske mål om forandring - særlig til fordel for marginaliserte grupper; underprivilegerte, særskilt begavede, sosialt mistilpassede, minoriteter og innflyttere - og de planene, strategiene og tiltakene som skal føre til forandring, viser seg som mest egnet til å konservere og befeste det bestående. Kategoriseringene av de som er i faresonen (at-risk) bidrar til å bekrefte deres utenforskap. Under ligger, hevder Popkewitz, et ikke uttalt behov for kontroll: Målet er å gjøre barna til veltilpassede og lojale borgere. Istedenfor inkludering skjer det motsatte, de marginaliserte barna og deres familier fastholdes som andre slags folk (kinds of people):

\footnotetext{
${ }^{4}$ Teksten det refereres til her, handler eksplisitt om forhold i USA.
} 
... the particular kinds of people that teachers are to act on and change. The urban, gifted, adolescent, at-risk, and socially disadvantaged child are such kinds of people that become the origin of teachers' «experiences» and which give intent and purpose to classroom practices (Popkewitz, 2013a, s. 126).

Standarden andre slags folk måles mot, det veltilpassede, aldersadekvate, ønskelige, normale, kulturelt gjenkjennelige eller norske, står imidlertid ikke fast dersom språket som beskriver de andre finslipes. Det gjør heller ikke forståelsen av forholdet mellom offentlig og privat, individ og kollektiv, rett og plikt. Endringene kan være ønskelige - eller slett ikke, men standardene endres umerkelig dersom vi ikke vender blikket også mot disse gjennom kulturell selvrefleksjon, noe lærerutdanningen må oppfordre studentene til å delta $\mathrm{i}$.

Kronprinsparets skolevalg kan tjene som prisme for en slik selvrefleksjon. I teksten som følger vil jeg skissere opp en historisk kontekst for valget; den norske kongefamiliens skolehistorie. Jeg vil kort peke på sammenhengen mellom konstitusjonen og skolelovgivningen, men først og fremst se på hvordan kongefamiliens skolevalg historisk og nå er blitt snakket om og fortolket i offentligheten, nærmere bestemt gjennom presse og media - og i tillegg altså i en undervisningssituasjon i grunnskolelærerutdanningen. Videre tilbyr jeg to alternative lesninger av kronprinsparets valg fra 2014. Disse peker innover i kulturen og framover mot framtida og må derfor betraktes som forslag - som utgangspunkt for diskusjon.

\section{De kongeliges skolegang}

Det er mange slags folk, og kongelige er en anakronistisk variant i moderne demokratier. De spiller like fullt virksomme roller i konstitusjonelle monarkiers forhandlinger om politisk og kulturell selvforståelse. De europeiske kongehusenes fortsatte legitimitet synes å ligge i nettopp deres evne til å gestalte samfunnsintegrasjonen i sine offentlige personer.

Republikanere anfektes gjerne av at kongelige arver sin posisjon. Fra et pedagogisk synspunkt er det minst like anfektende at barn fødes inn i en rolle som gjør deres liv politisk og som styrer deres mulighet for selvbestemmelse. Vurderingen de voksne kongelige må ta, er om eller når denne prisen blir for høy. Kongelige barns liv er innskrevet i Grunnloven. De valgene foreldrene tar på barnas vegne, vil derfor være gjenstand for offentlig oppmerksomhet og legitim diskusjon. I det følgende skal jeg se nærmere på den norske kongefamiliens skolevalg ut fra en pedagogisk historisk og dermed samfunnspolitisk interesse. Også i Norge er Grunnloven en kulturell kontekst av stor betydning for forståelsen av hva samfunnet vil med skolen. Grunnloven gir dessuten kongefamilien en helt spesiell samfunnsintegrerende funksion.

Norge er fra 1814 et konstitusjonelt monarki, og ved unionsoppløsningen i 1905 ble det nåværende kongehuset valgt gjennom folkeavstemning (Stråth, 2005, s. 528). Regenten og tronarvingene er skrevet inn i en rekke av paragrafene i Grunnloven (Grunnloven, se særlig $\iint 3-11$ ). Kongefamilien - også barna - angår derfor offentligheten. I og med at kongens realpolitiske makt er avviklet, er det den symbolske rollen og funksjonen som $\mathrm{i}$ dag best begrunner at monarkiet opprettholdes. 


\section{Trude Evenshaug}

Denne rollen fordrer nærvær og deltakelse i nøye utvalgte situasjoner, noen er konstitusjonelle, som statsråd på slottet og Stortingets åpning, de fleste er det ikke. Kongen og hans hus må være synlig. Det norske monarkiet består så lenge folket, $\mathrm{i}$ betydningen Stortinget, slutter opp om det, eller så lenge den kongelige familie ønsker å fylle rollen. Det siste er også et mulig framtidig scenario: At det er en framtidig regent og dennes familie som slår opp med folket og ikke omvendt.

I tillegg til den synligheten som følger med rollene, har kongefamilien høy kjendisfaktor. Smått og stort som angår kongefamilien vekker offentlig interesse. Medie-trykket mot offentlige personer øker stadig, og kongefamilien har måttet gå opp noen grenser for hva som med legitim grunn må sies å ha offentlig interesse. Dette har i noen grad skjedd i samråd med pressen. ${ }^{5}$ Sammenliknet med andre land, er både presse og folk flest innstilt på å innrømme den norske kongefamilien et privatliv. Ikke minst er en opptatt av at barna må få vokse opp uten konstant medieovervåkning. ${ }^{6}$ Mediene er like fullt en avgjørende arena for kongefamiliens utøvelse av sin rolle.

Kongefamiliens utdanningsvalg regnes blant de begivenhetene som har offentlig interesse. I tre generasjoner er pressen blitt invitert med når den norske tronarvingen har begynt på skolen. Vår nåværende regent, daværende prins Harald, startet riktignok sin skolegang i eksil i USA under krigen. Han ble skrevet inn ved den offentlige folkeskolen i Oslo i september 1945. Dette ble først omtalt i små notiser i pressen, som eksempelvis denne i Sarpsborg Arbeiderblad: «Prins Harald ble tirsdag 11. ds. inn meldt [sic.] ved Aker folkeskole. Prinsen skal gå på Smestad skole og begynner i 3dje klasse» (Sarpsborg Arbeiderblad, 1945). Eller som Morgenbladet skrev: «Lille Prins Harald ble i går innmeldt ved Smestad folkeskole i tredje gutteklasse. Han var frisk og opplagt og deltok ivrig i leken på skoleplassen. Det er jo en oppvakt og frisk liten gutt, som skolen sikkert får stor glede av» (Morgenbladet, 2015).

Smestad skole var ny og moderne. Skolen ble åpnet i 1938, men etter invasjonen i 1940 ble den stengt og rekvirert som bolig for tyske soldater allerede 20. april. Den høytidelige gjenåpningen skjedde 21. november 1945, da kronprins Olav talte på

\footnotetext{
${ }^{5}$ Den såkalte barneparagrafen i pressens Vær varsom-plakat (se Pressens Faglige Utvalg, u.å. \4.8) ble første gang prøvet på bakgrunn av pressens eksponering av kronprinsesse Mette-Marits sønn, Marius, i 2002. Barneparagrafen var da nylig vedtatt av Norsk Presseforbund. Den var initiert av Norsk Journalistlags daværende nestleder, Ann-Magrit Austenå, og hun innklaget selv på privat initiativ, men med samtykke fra Slottet VG, Nettavisen og Se og Hør for mangel på god presseskikk etter den nye paragrafen (sak 062/02, 063/02 og 064/02, PFU-basen, u.å.). Overraskende og diskutabelt nok, ble ikke de tre mediene felt i Pressens Faglige Utvalg (PFU), men saken bidro til at den nye barneparagrafen ble kjent (se f.eks. Evenshaug, 2002; Omdal, 2002). Den offentlige refleksjonen rundt pressens selvstendige ansvar for barns særlige rett til beskyttelse mot konfliktorientert offentlig eksponering, kan ha bidratt til at pressen siden er blitt mer varsomme når det gjelder omtalen av både kongefamiliens barn og barn generelt.

${ }^{6}$ Da NRK Dagsrevyen inviterte kommentator i Dagens Næringsliv, Kjetil Wiedswang, og redaktør i Nettavisen, Gunnar Stavrum, for å diskutere kronprinsparets skolevalg i 2014, la programleder Ingvild Bryn premissene innledningsvis: Samtalen skulle dreie seg om tronarvingen, prinsesse Ingrid Alexandra, ikke om broren, prins Sverre Magnus (Dagsrevyen, 2014). Den samme begrensningen legger jeg i denne artikkelen av det som antakelig er samme grunn: Tronarvingen har en annen konstitusjonell status enn broren.
} 
vegne av foreldrene (Osloskolen, 2016). Denne begivenheten ble grundig dekket av pressen (jf. fotodokumentasion, NTB Scanpix, 2016a).

Mediedekningen av selve skolestarten til prins Harald høsten 1945 var altså smålåten og behersket. Tre måneder senere, på prins Haralds niårsdag, 21. februar 1946, inviteres imidlertid pressen til Smestad skole for å oppleve og videreformidle inntrykk fra prins Haralds hverdag som skolegutt. Norsk Telegrambyrås (NTB) pressefotografier fra seansen kan søkes opp i arkivene til NTB Scanpix (2016b). Bildene viser en (tilsynelatende) alminnelig etterkrigsgutt i en velbrukt strikkegenser, som står og sitter ved pulten sin i klasserommet sammen med de andre guttene $i$ klassen. Han rekker ivrig opp hånda for å svare på lærerens spørsmål, han regner på tavla og, ikke minst, han leker i snøen i skolegården, der han ender opp i et heftig (men vennskapelig - det smiles) basketak med en kamerat. Det siste dokumentert giennom en lengre fotoserie. Den lille prinsen er fortsatt «frisk og opplagt». Slike gutter vil gamle Norge ha.

Prinsens far, kronprins Olav, hadde sin skolegang avsondret fra vanlige barn, på slottet. Skolepulten i tre er blant klenodiene i De norske skolehistoriske samlinger, som for tiden er stuet vekk på et lager i Drammen. ${ }^{7}$ Kronprins Olav tok artium ved Halling skole og fikk deretter i likhet med sin far, en militær utdanning (Kongehuset, 2016). Det var vanlig at unge prinser fikk militær utdanning i til dels barske omgivelser (jf. Bomann-Larsen, 2002), men det var et brudd med sedvanlig europeisk fyrsteoppdragelse da prins Harald begynte i en vanlig, offentlig folkeskoleklasse i 1945. På det norske kongehus' nettsider beskrives dette slik:

Etter freden begynte den unge prinsen på Smestad skole i Oslo. Bortsett fra en sikkerhetsvakt på gangen, var det lite som skilte prinsens skolegang fra andre barns. For å fylle de krav man stiller til en moderne monark i dagens samfunn, ble det lagt vekt på at oppdragelsen skjedde med forankring i folket og samtiden (Kongehuset, 2016).

Effekten av det daværende kronprinsparets valg for prins Harald, kan neppe overvurderes. Kongefamilien var umåtelig populær etter krigen, og valget bidro til å stake ut en kurs for monarkiet som folkelig og den norske etterkrigskulturen som egalitær og sosialdemokratisk. Kongefamilien delte det norske folkets kår og var opptatt av å være nær og kjenne sitt folk. Denne følsomheten for tidsånden og hva denne krever av tilpasning og justering, har kjennetegnet det norske kongehuset.

For den offentlige norske skolen hadde skolevalget enorm symbolsk betydning. Kronprinsparets valg kronet bokstavelig talt det norske enhetsskoleprosjektet. Prosjektet hadde som forutsetning at den offentlige skolen i Norge måtte bli så god at eliten ville sende barna sine dit. Nå var prosjektet fullført ${ }^{8}$ : Den offentlige norske skolen var for alle, også prinser og prinsesser.

\footnotetext{
${ }^{7}$ De norske skolehistoriske samlinger ble i 2013 slått sammen med Drammens museum (Dagsavisen-Fremtiden, 2013), men er ikke synlige i museets tilgjengelige samlinger, verken i museet eller på nett (Drammens museum, 2016).

${ }^{8}$ Dette er en sannhet med store modifikasjoner. Kampen for en inkluderende skole, som også hadde plass til barn med særskilte behov for tilpasning, fortsatte.
} 


\section{Trude Evenshaug}

Den nåværende kronprins Haakons skolestart i 1980 skjedde på samme skole som farens, Smestad i Oslo. Dette ble naturligvis også dekket av pressen (se f.eks. VG, 1980). Det er verdt å merke seg at verken Harald eller Haakon gikk på skolen i nærmiljøet der de bodde, på Skaugum i Asker. Her stanser likheten med vanlige norske barns skolegang, der regelen er at barn går på skole i skolekretsen der de bor. I 1986 begynte prins Haakon Magnus på ungdomsskolen, og da falt valget på private Kristelig Gymnasium (KG) i Oslo. Der faren gikk på offentlige Oslo Katedralskole, tok familien nå et annet valg for sønnen. Kristelig Gymnasium ble opprettet i 1913 av en rekke kristne organisasjoner (KGs nettside, 2016). Den ble drevet etter Privatskolelova, mottok offentlig støtte og hadde forholdsvis lav egenbetaling. I 1986 hadde skolen både ungdomsskole og videregående skole. Både prins Haakon Magnus og søsteren, prinsesse Märtha Louise, begynte på skolen samtidig. Han i 7 . klasse og hun i 9. klasse. Haakon var elev ved skolen til han var ferdig med videregående skole i $1992 .^{9}$

Det nåværende kronprinsparets datter, prinsesse Ingrid Alexandra, ble født i 2004 . Hun er den andre i arverekken til den norske tronen. Som framtidig dronning vil hennes personlige liv være regulert av en rekke paragrafer i den norske Grunnloven, se særlig $\iint$ 3-11. Faktisk er det paragrafer som allerede nå regulerer hennes liv. Én paragraf nevner til og med kongens (eller dronningens) oppdragelse: «Bestyrelsen av den umyndige konges oppdragelse bør, hvis begge foreldrene er døde og ingen av dem har etterlatt noen skriftlig bestemmelse derom, fastsettes av Stortinget» (Grunnloven, \47). Paragrafen vil forhåpentlig aldri komme til anvendelse. Som vi ser, har de kongelige foreldrene et primært pedagogisk mandat når det kommer til deres barns oppdragelse og skolegang - også når barnet er tronarving. Så hva gjør de?

I januar 2006 starter to år gamle prinsesse Ingrid Alexandra i den lokale barnehagen nær Skaugum i Asker. I august 2010 begynner hun i 1. klasse på nærmiljøskolen, Jansløkka. Og så, i juni 2014 blir det kjent at både hun og lillebroren, prins Sverre Magnus, fra skolestart den kommende høsten skal tas ut av Jansløkka skole og begynne på to forskjellige private skoler. Ingrid Alexandra begynner i 5 . klasse på Oslo International School på Bekkestua i Bærum i august 2014 (se Kongehuset, 2016). Dette er en skole der undervisningen foregår på engelsk. Skolen er særlig beregnet på utenlandske familier som har opphold i Norge en begrenset tid, men den ønsker også velkommen lokale innbyggere «som er interessert $\mathrm{i}$ en utfordrende internasjonal utdanning» (Oslo International School, 2016 min overs.). Og så kunne en legge til: som har god økonomi. Skolepengene beløper seg til godt over 200.000 kroner pr. år. Skolen har et begrenset antall plasser for norske elever. Disse søker om redusert skolepengesats idet de søker opptak (opplyst av rektor Janecke Aarnæs i epost 10.05.2016).

Redusert sats for norske elever er om lag 100.000 kroner pr. år, inkludert diverse avgifter. Dersom kvoten for redusert sats er oppbrukt, kan man stå på venteliste eller få opptak på ordinære vilkår (Oslo International School, 2016, Admission/School fees).

\footnotetext{
${ }^{9}$ Examen artium var avskaffet da kronprins Haakon gikk ut av videregående skole i 1992. Kongehusets omtale av kronprinsens «artium» er derfor ikke helt presis (se Kongehuset, 2016).
} 
Flere norske profilerte investorer, deriblant tidligere president i Norges Rederiforbund og Næringslivets hovedorganisasjon, Jens Ulltveit-Moe, har latt seg intervjue som fornøyde foreldre ved skolen (VG nett, 2016). Det er med andre ord ikke fortegnet å si at skolen prinsessen går på, er en eliteskole. Skolen tilbyr naturligvis et internasjonalt miljø, men det kulturelle mangfoldet begrenser seg ventelig til barn fra et begrenset sosioøkonomisk sjikt.

\section{Kronprinsparets skolevalg: En lesning ${ }^{10}$}

Alle barn i Norge har plikt til grunnskoleopplæring og rett til å få denne opplæringen i offentlig skole. Opplæring utenom den offentlige skolen må være godkjent og i samsvar med lov og forskrifter (Opplæringslova, 1998, $\$ 2-1$ ). Det er to måter private skoler kan få statlig godkjenning på, enten etter Friskolelova (2003) (loven skiftet navn fra Privatskolelova til Friskolelova i 2015) eller etter Opplaringslova $\ 2-12$. Det første utløser statsstøtte, det siste giør det ikke. Privatskoler som godkjennes etter Opplæringslova er unntatt flere krav, noe som gir elevene færre rettigheter - for eksempel retten til spesialundervisning. Privatskoler som er godkjent etter Opplæringslova kan ha internasjonale læreplaner. I slike skoler vil norsk være å betrakte som fremmedspråk, selv om det er krav til egen læreplan i norsk for elever som har norsk som morsmål. På Oslo International School innebærer planen Norvegian $A$ også religion, med læringsmål fra KRLE, mens Norwegian $B$ og Norwegian for beginners har norsk kultur, samfunnsliv og historie på planen (Oslo International School, 2016, Academics). Skolen gir ingen opplæring i sidemål.

Da det ble kjent for offentligheten at prinsessen ikke kommer til å ha nynorsk på skolen (VG nett, 2016), skrev slottets kommunikasjonssjef i en e-post til VG? «Foreldra syter for at ho får naudsynt opplæring i nynorsk» (ibid.). Til Dagbladet sier kronprinsessen:

Nynorsk er en veldig viktig del av norsk identitet og kultur. Det er viktig for mange som har det som morsmål. Og det er vår jobb som foreldre å sørge for at prinsessen blir opplært i nynorsk. Det er vi veldig bevisste på og giør hjemme (Dagbladet, 2016).

Kronprinsesse Mette-Marit sier videre til avisa at de har «iverksatt flere tiltak» for at prinsessen skal lære nynorsk. Hun viser blant annet til at Ingrid Alexandra leste diktet $A$ vere $i$ livet av Halldis Moren Vesaas i forbindelse med kongeparets 25-årsjubileum (Dagbladet, 2016). Festforestillingen i Universitetets aula ble sendt direkte i NRK fjernsynet 17. januar 2016.

Prinsessens flotte diktopplesning som hun framførte sammen med faren, rørte mange (se NRK TV, 2016). Da nyheten om at prinsessen ikke lærer nynorsk på skolen kom en måneds tid etterpå, fortonte det hele seg imidlertid annerledes: som forebyggende skadebegrensning. ${ }^{11}$ Etter nærmere 200 år med målstrid og over

\footnotetext{
${ }^{10}$ En lesning innebærer at teksten ikke utsier noe om kronprinsparets motiver, tanker, intensjoner eller holdninger. Lesningen forholder seg til det kronprinsparet sier og gjør, som er synlig for offentligheten.

${ }^{11}$ Artikkelforfatteren har bakgrunn som journalist og kommunikasjonsdirektør, så denne vurderingen bygger på kjennskap til strategisk kommunikasjon.
} 


\section{Trude Evenshaug}

100 år med to likestilte offisielle norske målformer, er det oppsiktsvekkende at det norske kronprinsparet har tatt sjansen på å gi tronarvingen en skolegang uten sidemålsopplæring. Grunnen til at det synes å aksepteres kan kanskje være at hun går i en skole der norsk som sådan er fremmedspråk. På 1700-tallet var det fransk som var dominerende blant kongelige og adel i hele Europa, ikke de nasjonale språkene. I dag ser de ut til å velge engelsk.

At prinsessen ikke lærer nynorsk på skolen er altså fanget opp av media. At skolen har elitepreg med hensyn på økonomi, er nøye omtalt (se f.eks. NRK nett, 2014). Men så langt har det ikke vært tilsvarende oppmerksomhet om fraværet av en annen type mangfold enn den som representeres ved flerkultur: Oslo International School drives på bakgrunn av godkjenning etter Opplæringslova $\ 2-12$ og er derfor ikke forpliktet til å tilby spesialundervisning. Det gjør den da heller ikke, og på nettsidene opplyses det at skolen for øvrig bare kan håndtere små lærevansker. Skolen tar verken imot elever med lav kognitiv fungering eller atferdsvansker (Oslo International School, 2016, Admissions/Admission policy).

I læreplanverkets prinsipper for opplaringen omfatter begrepet mangfold variasjoner i bakgrunn, forutsetninger, interesser og talent (Utdanningsdirektoratet, 2016). På Utdanningsdirektoratets nettsider understrekes det at inkludering bygger på prinsippet om likeverd:

I skolen må likeverd praktiseres blant annet gjennom fellesskapet mellom elever med ulike forutsetninger. Likeverdig opplæring innebærer at elevene ikke behandles likt, men forskjellig ut fra de ulike behovene de har. Skolen skal derfor utvikle et fellesskap mellom elevene uavhengig av elevenes kjønn, sosiale bakgrunn eller evner og forutsetninger (Utdanningsdirektoratet, 2015).

I henhold til skolemyndighetenes egen språkbruk kan Oslo International School dermed vanskelig omtales som inkluderende og den må kunne sies å være fattig $p a ̊$ mangfold. ${ }^{12}$ At kronprinsparet velger en skolegang for sin datter der hun ikke får mulighet til å gå på skole i et inkluderende og mangfoldig læringsfellesskap, sender tunge signaler til det norske samfunnet: Det er mange slags folk (jf. Popkewitz over) som anses irrelevante - ja, kanskje til og med forstyrrende - for prinsessens læring, utvikling og danning. Disse skal hun slippe å gå på skolen med. Og norske politikere fra partier som har kjempet fram ideen om inkludering og fellesskap, nikker og smiler og gjemmer seg bak nyliberale talemåter om den enkelte families frie valg. ${ }^{13}$ Dette frie valget er det ikke så mange i Norge som reelt sett kan ta.

Kronprinsparet velger altså vekk muligheten for at tronarvingen skal få være i daglig kontakt med medelever som nyter godt av spesialpedagogisk hjelp eller som trenger

\footnotetext{
${ }^{12}$ For en nærmere drøfting av begrepene mangfold og inkludering i en utdanningsvitenskapelig sammenheng, se Morken (2009).

${ }^{13}$ Se både tidligere (Trond Giske, Ap) og nåværende (Torbjørn Røe Isaksen, H) kunnskapsministers uttalelser til NRK (NRK nett, 2014, 17.06.2014). Arbeiderpartiets Jonas Gahr Støre, derimot, uttalte seg kritisk om kronprinsparets begrunnelse for valget i et intervju med avisen Vårt Land (Vårt Land, 2014).
} 
annen særskilt tilrettelegging. Dersom en leser dette signaltunge valget opp mot regjeringen Solbergs opprinnelige forslag til forskrift om rammeplan for de nye femårige grunnskolelærerutdanningene (Kunnskapsdepartementet, 2015), tegner det seg et urovekkende bilde. Forslaget åpnet ikke for at lærerstudenter skulle kunne velge spesialpedagogikk som masterfag. Konsekvensen av forslaget ville være at lærere som ville opparbeide seg spesialpedagogisk kompetanse på masternivå, måtte ta to mastergrader. Peder Haug karakteriserte forslaget som et kraftig ideologisk skifte for spesialundervisningen:

Vi får ikkje lenger velutdanna spesialpedagogar som har undervisningskompetanse og inngåande systemkunnskap. Dei «nye» spesialpedagogane vil i framtida truleg ha studert spesialpedagogikk utan tilknyting til lærarutdanninga, og teke rein bachelorog mastereksamen i faget. Då får vi «reine» spesialpedagogar, og det kan føre til at vi får eit endå større skilje mellom ordinær opplæring og spesialundervisning enn det vi har i dag. Det var ikkje meininga med ein inkluderande skule, og dette skjer utan grundig debatt (Haug, 2016 s. 14).

Etter at forslaget hadde vært ute til høring, åpnet departementet likevel for at lærerstudenter kan velge spesialpedagogikk som masterfag (Kunnskapsdepartementet, 2016), men forslaget viser at den tenkningen om inkludering som har preget norsk skole i årtier, er under press. Kronprinsparets skolevalg vil dermed kunne forsterke en skolepolitisk dreining vekk fra den inkluderende fellesskolen. Deres gestaltning av samfunnsintegrasjonen setter opp igjen gjerder som har vært forsøkt revet: gjerder mellom de av oss, som er representert av kongefamilien, og de andre som helt konkret er definert vekk, i og med skolevalget. Den norske skolehistorien om en skole for alle preget av inkludering, mangfold og fellesskap, settes i revers.

En annen svært relevant kontekstuell særegenhet som er nødvendig å kjenne til for å fortolke kronprinsparets skolevalg på en adekvat måte, er det lave innslaget av privatskoler i Norge. Private skoler har vært betraktet som en demokratisk sikkerhetsventil, et unntak, som til nød har vært akseptert av en tung skolepolitisk aktør som Arbeiderpartiet. Tidligere var det bare religiøse og pedagogiske alternativ som ble godtatt, og de har alltid stått under strengt tilsyn. Den offentlige skolen har historisk hatt svært høy oppslutning i Norge. 3,5 prosent av grunnskoleelevene går i dag i private skoler (Statistisk sentralbyrå (SSB), 2015). Langt de fleste av disse går i skoler som er godkjent etter Friskolelova, der virksomheten ligger tett opp til den offentlige skolen, og der skolen derfor mottar offentlig støtte. Egenbetalinger som den Oslo International School opererer med, er med andre ord svært uvanlig.

3,5 prosent er likevel et historisk høyt tall. Den offentlige skolen er under press. I en spørreundersøkelse VG fikk foretatt om kronprinsparets skolevalg, svarte godt under halvparten av de spurte at tronarvingen burde gå i offentlig norsk skole. 37,5 prosent svarte at dette var en privatsak, mens ti prosent mente at kronprinsparets barn burde gå i privat skole. Ti prosent visste ikke hva de mente om saken (VG nett, 2014). Øyeblikksbildet fra en tredjeklasse i lærerutdanningen (se over side 2), bekrefter inntrykket av at ikke bare prinsessen, men også halve kongeriket er i ferd med å glippe for den offentlige norske skolen. Dette markerer et tydelig brudd med etterkrigstidas 


\section{Trude Evenshaug}

massive oppslutning om det norske enhetsskoleprosjektet. Og det skjer så å si helt i det stille. Den erklærte republikanske avisa Dagbladet meldte riktignok om storm på bakgrunn av kronprinsparets skolevalg (Dagbladet, 2014), og det var kritiske røster som lot seg høre, ${ }^{14}$ men dersom VGs meningsmåling kan gjelde som uttrykk for holdningen hos «folk flest», synes disse å akseptere valget. Det resonansrommet som både studenter, sentrale politikere og Utdanningsforbundets daværende leder (se NRK nett, 2014) tolker kronprinsparets skolevalg innenfor, bærer preg av det vi kunne kalle pedagogisk informerte talemåter, som setter barnas beste i sentrum. Til NRK sa Utdanningsforbundets leder Ragnhild Lied det slik:

Selv om Kronprinsparet er offentlige personer som selvfølgelig sender signaler gjennom sine handlinger, er de også foreldre som må ta valg på vegne av barna sine. Det kan være mange grunner til at Kronprinsparet har valgt denne løsningen, grunner de som familie må få lov til å ha for seg selv (NRK nett, 2014).

Denne vennlige, men litt ulne, pedagogisk korrekte og avvæpnende kommentaren kan tyde på at det er sider ved kronprinsbarnas skolebytter som verken kan eller bør sies høyt. Det som imidlertid taler høyt - og som er det den norske offentligheten har å forholde seg til - er valget av Oslo International School for tronarvingen (det fantes andre mulige valg) og den offisielle begrunnelsen kronprinsparet valgte å gi for dette: Kronprinsparets begrunnelse for skolebyttet var at tronarvingen trengte «et grunnleggende nivå for å tenke, snakke og skrive på engelsk» (Slottets kommunikasjonssjef til VG, 18.06.2014, VG nett, 2014).

Mens dette skrives går diskusjonen høyt om Høyres programkomités forslag om en nasjonal kulturkanon, er en god idé. Kunnskapsminister Torbjørn Røe Isaksen leder komiteen, og han begrunner forslaget med en underliggende bekymring for samfunnsintegrasjonen: Det «er viktig å se på hva som er felles for hele det norske samfunnet. [...] I en fragmentert tid er det viktig med kunnskap om den norske kulturarven: hvem er vi, hvor kommer vi fra og hvor skal vi? Vi trenger mer innsikt i våre felles røtter, og vi trenger et offentlig rom for refleksjon rundt disse spørsmålene» (Isaksen til Aftenposten, 2017, 11.01.2017). Imens går kronprinsparet foran og setter bekymringen på spissen. Som en elitens avantgarde toger de ut av den offentlige norske fellesskolen med den begrunnelsen at den norske skolen ikke duger i en globalisert, engelskspråklig verden. Dette skjer i et sosialt, politisk og kulturelt rom som særlig siden det såkalte Pisa-sjokket i 2001 (Utdanningsdirektoratet, 2011), har vært generelt bekymret over kvaliteten i den norske skolen. Flere vil følge etter kronprinsparet: Den norske skolen er ikke lenger god nok for eliten. Det gamle enhetsskoleprosjektet, som hadde nasjonal integrasjon som ett av sine fremste mål, gir ikke lenger de rette framtidsutsiktene for elitens barn. Pisa-resultatene taler for seg.

Prinsesse Ingrid Alexandra er den eneste norske skoleeleven som (indirekte) omtales i den norske Grunnloven. Ironisk nok forbyr den henne som framtidig dronning å oppholde seg utenfor Norges grenser mer enn seks måneder om gangen

\footnotetext{
${ }^{14}$ Se for eksempel den poengterte og velformulerte kritikken fra lærer Ane Krogsæter Aarre på NRK Ytring (Aarre, 2014).
} 
uten Stortingets tillatelse (Grunnloven, $\$ 11$ ). Like fullt mener altså foreldrene at hun som barneskoleelev trenger en internasjonal skolegang, ikke en norsk. Den ressurssterke familien ser seg i stand til å lære henne nynorsk hjemme, men synes ikke å se det paradoksale $\mathrm{i}$ at de (vel) har en bedre anledning enn de fleste til å gi datteren rikelig anledning til å «tenke, snakke og skrive på engelsk». ${ }^{15}$ Kongehusets jobb er å være symbolbærer og gestalte fellesskapet. Skolevalget taler i kraft av dette. Signalet som sendes, er at prinsessen forberedes for et liv blant den globale eliten. Hun utdannes $u t$ av det norske valg-monarkiets nøye tilkjempede norskhet, der de kongelige hittil har lagt vinn på å framstå som «gode nordmenn». På denne måten bidrar Kongehuset kanskje til sin egen avvikling.

En annen tolkning er imidlertid også mulig. Hvis vi vender tilbake til Tröhlers advarsel mot å skrive de nasjonale skolehistoriene inn i de store fortellingene om globale trender, representerer fortolkningen av kronprinsparets skolevalg et kritisk punkt for forståelsen av den norske skolen, og dermed det norske samfunnet. Stikkordet er synspunktet som ble målbåret av både lærerstudenter og «folk flest» i VGs meningsmåling:

Kronprinsparets skolevalg ble forstått som en privatsak. Og som politikerne referert over sa: Barnas skolegang må være opp til den enkelte families frie valg (se note 13). Utsagnene er tvetydige. Grunnskoleopplæringen er ikke en privatsak for noe barn i Norge, heller ikke for prinsessen og hennes familie. Som Tröhler har vist, er opplæringen av samfunnets barn i høyeste grad et offentlig anliggende. I Norge har det vært slik siden konfirmasjonsplikten ble innført i 1736. I dag er opplæringsretten og opplæringsplikten regulert av Opplæringslova og detaljert forskriftsfestet gjennom læreplanverket. Det norske skolesystemet er strengt regulert. Foreldre som velger hjemmeundervisning må følge den nasjonale læreplanen under nøye offentlig tilsyn. Det samme må private skoler, som drives i henhold til Friskolelova og i noen grad de private skolene som drives etter Opplæringslovas $\ 2-12$. Framtidige regenters oppdragelse står endatil omtalt i Grunnloven. Når det kommer til norske barns skolegang er det private både politisk og et støyende offentlig anliggende.

Skolen er dessuten et sted for store politiske investeringer. Troen på at framtida lar seg planlegge gjennom skolereformer ligger dypt i den politiske kulturen. Skolen skal ta seg av alt, ordne opp i alt, rydde, redde og sørge for at vi beholder kontroll over framtida. I følge Popkewitz lar ikke denne troen seg godt begrunne (Popkewitz, 2011), men den synes på ingen måte forlatt om en ser på den stadige reformiveren i skolepolitikken. Dersom «den enkelte familie» likevel og paradoksalt nok overlates til å være sin egen lykkes smed, og fellesskolen er en døende idé, bør dette diskuteres åpent. Og lærerstudenter som fortsatt stilles i utsikt at de har en framtid i en offentlig skole basert på et samfunnsmandat, bør settes i stand til å delta i samtalen.

\footnotetext{
${ }^{15}$ Det året prinsessen begynte på skolen, tok for eksempel kronprinsparet barna ut av skole og barnehage i to måneder for å reise på det kronprinsen omtalte som en «dannelsesreise» til India, formodentlig en anledning også til å praktisere engelsk (se NRK nett, 2010; NRK TV, 2010).
} 


\section{Trude Evenshaug}

\section{For hvem er skolen en privatsak?}

Til slutt skal jeg belyse spørsmålet om skolen som privat, versus offentlig anliggende, fra en annen ende. Som antydet over, kan det hende kronprinsparets skolevalg ikke er et varsel om avvikling av monarkiet, men snarere et uttrykk for det som allerede utspiller seg i og mellom de gamle, anakronistiske nasjonalstatene: Utenfor de nasjonale myndighetenes kontroll, utfolder en global elite seg på den globale scenen. Denne gis så å si frie tøyler, i en slags uuttalt forestilling om at det de holder på med, er bra for oss. Imens vender nasjonalstatens myndigheter (støttet opp av høylytte krav fra velgerne) oppmerksomheten mot det som fortsatt skaper frykt, nemlig mangelen på kontroll med en type folk (kinds of people) vi ikke vet om vi kan stole på.

De fleste former for folkeopplysning har et iboende paternalismeproblem, og det norske folkeopplysningsstevet på 1800-tallet er ikke noe unntak (Evenshaug, 2016): De som ser opplysning eller utdanning som et svar, har som regel stilt spørsmålet og mener selv å vite svaret. I den nye staten Norge, som ikke lenger var styrt av en eneveldig konge, skulle folkeopplysning og skole skape samhold, lojalitet, orden og kontroll. Middelet var å bli norske sammen. Denne historien har stygge sider, som fornorskingen av samene. Spørsmålet er om vi er i ferd med å begå liknende stygge overgrep igjen, og spørsmålet er om eliten igjen - eller fortsatt - ikke er villig til å risikere noe i møtet med de andre. Kongefamilien kan igjen synes å gripe den norske tidsånden. Denne gangen i en bevegelse mot et samfunn der vi slår fast at det er forskjell på folk.

I flere år nå, men intensivert høsten 2015, har Norge og verden vært stilt overfor millioner av barn på flukt. De har akutt behov for omsorg så vel som utdanning. Vi kunne kalle dem vår internasjonale utfordring og vårt transnasjonale håp. I februar 2016 trykket en norsk avis et flott bilde av ni år gamle «Lila» ${ }^{16}$ sammen med læreren $\mathrm{i}$ en velkomstklasse på en skole i en by i Norge. Bildet gjør inntrykk som uttrykk for en genuin pedagogisk situasjon. Lila er den andre prinsessen i denne historien. Hun er kommet til Norge som flyktning fra Syria. Reportasjen i avisa yter fortjenstfull motstand mot det massive inntrykket av fare, som mediebildet har vært preget av siden høsten 2015. Den tegner et optimistisk, rørende og positivt bilde av nyankomne elevers glede over å være tilbake på skolen. Spørsmålet er imidlertid: Hvem er opptatt av hvorvidt Lila kan «tenke, snakke og skrive på engelsk», og hennes muligheter til å kunne svinge seg $\mathrm{i}$ en globalisert verden? Lærerne hennes vil nok være det, men det store samfunnsoppdraget som formidles til lærerstudenter og lærere når det gjelder «folk som» henne, synes å være et annet. Hun har allerede dyrekjøpt internasjonal erfaring. Det blir ikke betraktet som en fordel. Den store bekymringen er snarere hvorvidt hun vil «lære seg norsk» og omfavne «våre verdier», slik at hun blir «integrert». Oppsummert handler det om: Vil hun bli en lojal borger? Kan vi stole på at hun blir en god nordmann? Dette har alltid vært maktens spørsmål i de konstitusjonelle nasjonalstatenes tid og er det fortsatt. I Norge i dag er det folk flest, alle som bor her og har stemmerett, som er makten. Dette bør lærerstudenter settes i stand til å oppdage, slik at de ikke daglig bekrefter nyankomne barns utenforskap med sin pedagogikk.

\footnotetext{
${ }^{16} \mathrm{Jeg}$ har valgt å anonymisere jenta, slik at ikke min lesning skal hefte ved henne. Av samme årsak er læreren, skolen, byen og avisa allmenngjort.
} 
Skolen er ikke en privatsak for Lila. Her vil norske myndigheter følge nøye med og være på alerten med krav og retningslinjer, planer og tiltak. ${ }^{17}$ Foreldre som flykter fra krig med sine barn, blir mistenkeliggjort i den norske offentligheten. Deres valg anerkjennes ikke som forsøk på det vi regner som riktig og selvsagt foreldreatferd, nemlig å velge det som er best for barna. Den pedagogisk informerte språkbruken som tas i bruk for å beskrive kronprinsparets valg for sitt konstitusjonelt innskrevne og symbolbærende barn, mobiliseres ikke i møte med foreldre på flukt. Dette bør norske lærerstudenter få anledning til å granske nøyere. Hva handler dette om? Hvorfor er ikke folk folk? Dette er ikke så lett å få grep om, dersom blikket bakover ikke går lenger enn til forrige læreplan, eller skolehistorien iscenesettes som en fornuftens og norskhetens seiersgang gjennom tiden. ${ }^{18}$ Studentene må inviteres til å snakke kritisk pedagogikk til virkelighet og fortelle nye norske eventyr der den andre prinsessen vinner både Askeladden, halve kongeriket og resten av verden med.

\section{Referanser}

Aarre, A. K. (2014, 20.06.2014). Når kongehuset meiner at vi ikkje strekk til. Hentet 10.05.2016, fra http://www. nrk.no/ytring/kronprinsparets-val-er-ikkje-greitt-1.11786463

Aftenposten. (2017, 11.01.2017). Høyre vil kåre det beste av norsk kunst og kultur. Hentet 13.01.2017, fra http://www.aftenposten.no/kultur/Hoyre-vil-kare-det-beste-av-norskkunst-og-kultur-61 1950b.html

Biesta, G. J. J. (2011). Disciplines and theory in the academic study of education: A comparative analysis of the Anglo-American and continental construction of the field. Pedagogy, Culture and Society, 19(2), $175-192$.

Biesta, G. J. J. (2013). А̊ snakke «pedagogikk» til «education»: Internasjonalisering og problemet med konseptuell hegemoni i studiet av pedagogikk. Norsk pedagogisk tidsskrift, 97(03), 172-83.

Bomann-Larsen, T. (2002). Kongstanken. Oslo: Cappelen Damm.

Dagbladet. (2014, 18.06.2014). Fjerner seg fra folket, s. 1.

Dagbladet. (2016, 09.03.2016). Mette-Marit: - Vär jobb à lere prinssessen nynorsk. Hentet 09.05.2016, fra http:// www.dagbladet.no/2016/03/09/kultur/litteratur/kongehus/prinsesse_ingrid_alexa ndra/nynorsk/43448090/

Dagsavisen-Fremtiden. (2013, 04.10.2013). Skolehistorie får stryk. Hentet fra http://www.dagsavisenfremtiden. no/lokalt/skolehistorie-far-stryk-1.295573

Dagsrevyen. (2014 18.06.2014). Reportasje og diskusjon om kronprinsparets skolevalg. Hentet 10.05.2016, fra https://tv.nrk.no/serie/dagsrevyen/NNFA19061814/18-062014

Depaepe, M. (2001). A Professionally Relevant History of Education for Teachers: Does it Exist? Reply to Jurgen Herbst's State of the Art Article. Paedagogica Historica, 37(3), 629-640. doi: 10.1080/ 0030923010370305

Depaepe, M. \& Simon, F. (2011). Sources in the making of histories of education: proofs, araguments, and other forms of reasoning from the historian's workplace. ŠUMADIFSKI ANALI [Annals of Šumadija], 5(6), 143-165.

Doney, J. (2015). Rethinking the History of Education: Transnational Perspectives on its Questions, Methods and Knowledge. [Book review]. History of Education: Fournal of the History of Education Society, 44:2, 245-247. doi: 10.1080/0046760X.2014.966786

Drammens museum. (2016). Drammens Museum. Hentet 09.05.2016, fra http://drammens.museum.no/

Evenshaug, T. (2001). Å lese og skrive pedagogisk historie. I H. Jarning (Red.), SKOLEN 2001. Årbok for norsk utdanningshistorie. Oslo: Stiftelsen Årbok for norsk utdanningshistorie.

\footnotetext{
${ }^{17}$ I skrivende stund er nyheten om at integreringsministeren vil premiere flyktninger som lærer norsk fort, toppoppslag i NRK Dagsrevyen (NRK nett, 2016). De som ikke oppfyller «kravene», får dårligere livsvilkår.

${ }^{18}$ Jf. Hayden Whites teori om historieskrivningens emplotments (White, 1987 [1973]).
} 


\section{Trude Evenshaug}

Evenshaug, T. (2002, 31.05.2002). Tøvete av fan E. Hansen. Hentet 05.05.2016, fra http://journalisten.no/ story/40093

Evenshaug, T. (2016). A Relocated Answer to the Question: What is Enlightenment? History of European Ideas. doi: 10.1080/01916599.2016.1161534

Friskolelova. (2003). Lov om frittståanda skolar. Hentet 09.05.2016, fra https://lovdata.no/dokument/NL/lov/ 2003-07-04-84?q=friskoleloven

Grunnloven. Kongeriket Norges Grunnlov. Hentet 03.05.2016, fra https://ovdata.no/dokument/NL/lov/181405-17

Haug, P. (2016). Kva rolle har pedagogikken hatt i lærarutdanninga? Lektorbladet, 2, $12-14$.

Herbst, J. (1999). The History of Education: State of the Art at the Turn of the Century in Europe and North America. Paedagogica Historica, 35(3), 737-747. doi: 10.1080/0030923990350308

Hofstetter, R., Fontaine, A., Huitric, S. \& Picard, E. (2014). Mapping the discipline history of education. Paedagogica Historica, 50(6), 871-880. doi: 10.1080/00309230.2014.948017

Hunt, L. (Red.). (1989). The New Cultural History. Studies on the History of Society and Culture. Berkeley: University of California Press.

KGs nettside. (2016). KG 100 år. Hentet 09.05.2016, fra https://www.kg.vgs.no/

Kongehuset. (2016). Det norske kongehus. Hentet 05.05.2016, fra http://www.kongehuset.no

Kunnskapsdepartementet. (2015). Høring - forskrifter om rammeplan for femårige grunnskolelcrerutdanninger. Hentet 08.05.2016, fra https://www.regjeringen.no/no/dokumenter/horing---forskrifter-om-rammeplanforfemarige-grunnskolelarerutdanninger/id2468914/

Kunnskapsdepartementet. (2016). Rundskriv F-06-16 Forskrifter om rammeplaner for femårige grunnskolelcererutdanninger for trinn 1-7 og trinn 5-10. Hentet 08.06.2016, fra https://www.regjeringen.no/no/dokumenter/ f-06-16/id2507752/?q= rammeplan $\% 20$ for $\% 20$ fem $\%$ C3\%A5rig

Morgenbladet. (2015, 11.09.2015). Morgenbladet for 70 år siden.

Morken, I. (2009). Mangfold, inkludering og minoritetshierarki i nasjonale læreplaner. I E. L. Dale (Red.), Lareplan - Et forskningsperspektiv (s. 154-186). Oslo: Universitetsforlaget.

NRK nett. (2010). Kronprinsparet tar barna ut av skolen og drar på to måneders ferie. Hentet 27.05.2016, fra http://www.nrk.no/norge/kronprinsparet-tar-lang-ferie-1.7366450

NRK nett. (2014, 18.06.2014). - Kronprinsparets valg av skole kolliderer med bildet av det folkelige kongehuset. Hentet 10.05.2016, fra http://www.nrk.no/norge/derforprovoserer-privatskolene-1.11784072

NRK nett. (2014, 17.06.2014). Kronprinsbarna bytter fra offentlig til privat skole. Hentet 06.05.2016, fra http:// www.nrk.no/norge/kronprinsbarna-til-privatskole-1.11781842

NRK nett. (2016, 10.05.2016). Pengepremier til fyktninger som larer fort: Sylvi Listhaug vil lage nye integreringsmottak der flyktninger blir premiert om de lerer norsk fort. De som ikke klarer kravene mister plassen på mottaket. Hentet 10.05.2016, fra http://www.nrk.no/norge/listhaug-vil-gi-penger-til-flyktninger-somlaerer-norsk-fort1.12939784

NRK TV. (2010). Kronprinsfamilien $i$ India. Hentet 27.05.2016, fra http://www.nrk.no/video/PS 25538

NRK TV. (2016, 17.01.2016). Kongepar $i 25$ år. Festforestilling $i$ Universitetets aula. Hentet 08.05.2016, fra https://tv.nrk.no/serie/kongepar-i-25-aar/MUHU17000016/17-012016

NTB Scanpix. (2016a). Bilde fra åpningen av Smestad skole 21. november 1945. Hentet 03.05.2016, fra http:// scanpix.no/spWebApp/preview/editorial/sp361c3a

NTB Scanpix. (2016b). Søk: Prins Harald Smestad skole. Hentet 03.05.2016, fra http://scanpix.no/spWebApp/ search.action?search.searchString $=$ Prins $\% 20$ Harald $\% 20$ Smestad $\% 20$ skole\&search.mainGroup = editorial

Omdal, S. E. (2002, 22.06.2002). Hvor mye må Marius tåle? Hentet 05.05.2016, fra http://www.aftenbladet.no/ meninger/fripenn/Hvor-mye-ma-Marius-tale-2735193.html

Opplæringslova. (1998). Lov om grunnskolen og den vidaregåande oppleringa. Hentet 09.05.2016, fra https:// lovdata.no/dokument/NL/lov/1998-07-17-61?q=oppl\%C3\%A6ringslova

Oslo International School. (2016). OIS - Oslo International School. Hentet 09.05.2016, fra http://www. oslointernationalschool.no/

Osloskolen. (2016). Smestad skole. Skolens historie. Hentet 03.05.2016, fra https://smestad.osloskolen.no/omskolen/om-oss/skolens-historie/

PFU-basen. (u.å.). Pressens Faglige Utvalgs database. Hentet http://presse.no/pfu/pfu-basen/

Plum, M. (2014). A 'Globalised' Curriculum: International comparative practices and the preschool child as a site of economic optimisation. Discourse - Studies in the Cultural Politics of Education, 35(4), 570-583. doi: $10.1080 / 01596306.2013 .871239$ 


\section{Da prinsessen og halve kongeriket glapp - om skole og samfunnsintegrasjon på norsk}

Popkewitz, T. S. (2011). The past as the future of the social and education sciences. I D. Tröhler \& R. Barbu (Red.), Education Systems in Historical, Cultural, and Sociological Perspectives (s. 163-181). Rotterdam: Sense Publishers.

Popkewitz, T. S. (2013a). The impracticality of practical knowledge and lived experience in educational research. Nordic Studies in Education, 33(2), 124-139.

Popkewitz, T. S. (2013b). Styles of Reason: Historicism, Historicizing, and the History of Education. I T. S. Popkewitz (Red.), Rethinking the History of Education. Transnational Perspectives on Its Questions, Methods, and Knowledge (s. 1-26). New York: Palgrave Macmillian.

Popkewitz, T. S. (Red.). (2013c). Rethinking the History of Education: Transnational Perspectives on its Questions, Methods, and Knowledge. New York: Palgrave Macmillan.

Popkewitz, T. S. (Red.). (2015). The "Reason" of Schooling. Historicizing Curriculum Studies, Pedagogy, and Teacher Education. New York: Routledge.

Pressens Faglige Utvalg. (u.å.). Var Varsom-plakaten. Hentet 05.05.2016, fra http://presse.no/pfu/etiske-regler/ vaer-varsom-plakaten/

Roos, M. (2014). Skolens rolle i nasjonsbyggingsprosessen. I J. H. Stray \& L. Wittek (Red.), Pedagogikk - en grunnbok (s. 93-105). Oslo: Cappelen Damm Akademisk.

Sarpsborg Arbeiderblad. (1945, 12.09.1945). Prins Harald på Smestad Skole. Hentet fra http://www.nb.no/ $\mathrm{nbsok} / \mathrm{nb} / 800226 \mathrm{cf0ed} 145393382295273 \mathrm{e} 846 \mathrm{ef}$ ?index $=179$

Statistisk sentralbyrå (SSB). (2015). Elevar i grunnskolen, 1. oktober 2015. Hentet 01.03.2016, fra http://www. ssb.no/utdanning/statistikker/utgrs/aar/2015-12-11\#content

Stråth, B. (2005). Union og demokrati. Dei sameinte rika Noreg-Sverige 1814-1905. Oslo: Pax Forlag A/S.

Tröhler, D. (2011). Languages of Education: Protestant Legacies, National Identities, and Global Aspirations. New York: Routledge.

Tröhler, D. (2013). Truffle Pigs, Research Questions, and Histories of Education. I T. S. Popkewitz (Red.), Rethinking the History of Education. Transnational Perspectives on Its Questions, Methods, and Knowledge (s. 75-92). New York: Palgrave Macmillian.

Tröhler, D. (2016). Curriculum history or the educational construction of Europe in the long nineteenth century. European Educational Research fournal, 15(3), 279-297. doi: 10.1177/14749041 16645111

Tröhler, D. \& Barbu, R. (Red.). (2011). Education Systems in Historical, Cultural, and Sociological Perspectives. Rotterdam: Sense Publishers.

Tønnessen, L. K. B. (2011). Norsk utdanningshistorie. En innføring med fokus på grunnskolens utvikling. Bergen: Fagbokforlaget.

Utdanningsdirektoratet. (2011). Internasjonale studier om norsk skole. Hentet 10.05.2016, fra http://www.udir.no/ Upload/Rapporter/temanotat/Internasjonale_studier_om_norsk_sk\%20ole_temanotat.pdf?epslanguage=no

Utdanningsdirektoratet. (2015, 08.09.2015). Tilpasset opplcering - inkludering og fellesskap. Hentet 05.10.2016, fra http://www.udir.no/laring-og-trivsel/tilpassetopplaring/inkludering-og-fellesskap/

Utdanningsdirektoratet. (2016). Tilpassa opplering og likeverdige føresetnader. Hentet 05.10.2016, fra http:// www.udir.no/laring-og-trivsel/lareplanverket/prinsipper-for-opplaringen2/tilpassa-opplaring-og-likeverdigeforesetnader/

VG. (1980, 19.08.1980). Første skoledag for sprudlende prins.

VG nett. (2014, 18.06.2014). 4 av 10 mener kronprins-barna burde gå på offentlig skole. Hentet 29.02.2016, fra http://www.vg.no/rampelys/kongehuset/4-av-10-menerkronprins-barna-burde-gaa-paa-offentlig-skole/a/ 23233977/

VG nett. (2016, 13.02.2016). Prinsesseskule utan nynorsk: - Uheldig at Ingrid Alexandra blir friteken. Hentet 11.04.2016, fra http://www.vg.no/nyheter/innenriks/skole-ogutdanning/prinsesseskule-utan-nynorsk-uheldig-at-ingrid-alexandra-blirfriteken/a/23613930/

VG nett. (2016, 16.02.2016). Investor Fens Ulltveit-Moe: (73): Er glad for at datteren slipper nynorsk. Hentet 09.05.2016, fra http://www.vg.no/nyheter/innenriks/skole-ogutdanning/investor-jens-ulltveit-moe-73-gladfor-at-datteren-slippernynorsk/a/23615346/

Vårt Land. (2014, 27.06.2014) Hentet 10.05.2016, fra http://www.vl.no/store-kritisererkronprinsparetsskolevalg-1.86219

White, H. (1987 [1973]). Metahistory. The Historical Imagination in Nineteenth-Century Europe. Baltimore and London: The Johns Hopkins University Press. 